\title{
Recent therapeutic advances in chronic lymphocytic leukemia
}

\section{[version 1; peer review: 2 approved]}

\author{
Prithviraj Bose1, Varsha Gandhi (D1,2 \\ ${ }^{1}$ Department of Leukemia, The University of Texas MD Anderson Cancer Center, Houston, TX, USA \\ ${ }^{2}$ Department of Experimental Therapeutics, The University of Texas MD Anderson Cancer Center, Houston, TX, USA
}

V1 First published: 31 Oct 2017, 6(F1000 Faculty Rev):1924

https://doi.org/10.12688/f1000research.11618.1

Latest published: 31 Oct 2017, 6(F1000 Faculty Rev):1924

https://doi.org/10.12688/f1000research.11618.1

\section{Abstract}

The last several years have witnessed a paradigm shift in the management of patients with chronic lymphocytic leukemia (CLL). The course of this very heterogeneous disease, traditionally treated with chemotherapeutic agents usually in combination with rituximab, typically has been characterized by remissions and relapses, and survival times vary greatly, depending on intrinsic biological attributes of the leukemia. The developments of the last few years have been transformative, ushering in an era of novel, molecularly targeted therapies, made possible by extensive efforts to elucidate the biology of the disease that predated the new targeted drugs. Thus, successful therapeutic targeting of the B-cell receptor signaling pathway and of the Bcl-2 anti-apoptotic protein with small molecules has now made chemotherapy-free approaches possible, hopefully mitigating the risk of development of therapy-related myeloid neoplasms and making eventual cure of CLL with the use of optimal drug combinations a realistic goal. Most importantly, these therapies have demonstrated unprecedented efficacy in patients with deletion 17p/TP53 mutation, a subset that historically has been very difficult to treat. However, as we gain more experience with the newer agents, unique safety concerns and resistance mechanisms have emerged, as has the issue of cost, as these expensive drugs are currently administered indefinitely. Accordingly, novel laboratory-based strategies and clinical trial designs are being explored to address these issues. The availability of whole exome/genome sequencing has given us profound insights into the mutational landscape of CLL. In this article, we highlight some of the most impactful advances since this topic was last reviewed in this journal.

Keywords

CLL , BCR pathway , ibrutinib , BTK, Bcl-2, venetoclax , CD20 antibody , PI3K

\section{Open Peer Review}

Approval Status

1

version 1

31 Oct 2017

Faculty Reviews are review articles written by the prestigious Members of Faculty Opinions. The articles are commissioned and peer reviewed before publication to ensure that the final, published version is comprehensive and accessible. The reviewers who approved the final version are listed with their names and affiliations.

1. Jacqueline Barrientos, Hofstra Northwell School of Medicine, Hempstead, USA

2. Emili Montserrat, University of Barcelona, Barcelona, Spain

Any comments on the article can be found at the end of the article. 
Corresponding authors: Prithviraj Bose (pbose@mdanderson.org), Varsha Gandhi (vgandhi@mdanderson.org)

Competing interests: Relevant to this manuscript, Prithviraj Bose has nothing to disclose and Varsha Gandhi has received research grants from AbbVie, Acerta, Gilead, Infinity, Pharmacyclics, and Sunesis.

Grant information: The authors declared that this work was funded by National Institutes of Health (grants P30 CA016672), MD Anderson's CLL Moon shot program, and a CLL-GRF Alliance grant.

Copyright: $\odot 2017$ Bose P and Gandhi V. This is an open access article distributed under the terms of the Creative Commons Attribution License, which permits unrestricted use, distribution, and reproduction in any medium, provided the original work is properly cited.

How to cite this article: Bose $P$ and Gandhi V. Recent therapeutic advances in chronic lymphocytic leukemia [version 1; peer review: 2 approved] F1000Research 2017, 6(F1000 Faculty Rev):1924 https://doi.org/10.12688/f1000research.11618.1

First published: 31 Oct 2017, 6(F1000 Faculty Rev):1924 https://doi.org/10.12688/f1000research.11618.1 


\section{Introduction}

The pace of discovery, with respect to both biology and therapeutic targets, as well as that of drug approval, in chronic lymphocytic leukemia (CLL) has been particularly rapid in recent years, so much so that therapeutic advances made in the treatment of CLL were named the "advance of the year" in 2015 by the American Society of Clinical Oncology. This topic was last reviewed in this journal in 2014 by Stilgenbauer and colleagues ${ }^{1}$. In this article, we review more recent developments, focusing on new genomic information, novel targeted therapies, and emerging targets and drugs/drug combinations as well as new information that has accumulated on agents that had just been approved or whose approval was imminent when the last review was written, namely ibrutinib and idelalisib.

\section{Recent insights into the chronic lymphocytic leukemia genome and integration of mutational information into risk stratification systems}

A lot has been learned on the topic of somatic mutations in CLL since the initial reports in 2011 (reviewed in 2). Two recent studies employing next-generation sequencing (either whole exome or whole genome) molecularly annotated nearly 1,000 CLL samples, identifying previously unrecognized putative driver mutations (for example, in ZNF292, ZMYM3, ARID1A, PTPN11, $R P S 15$, and $I K Z F 3$ ), including some in non-coding DNA (for example, the $3^{\prime}$ region of NOTCH1 that leads to aberrant splicing and increased NOTCH1 activity, and an enhancer located on chromosome 9p13 that results in reduced expression of PAX5), and many subclonal mutations and documenting frequent clonal evolution, even in the absence of therapy ${ }^{3,4}$. SF3B1 and NOTCH1 (previously described) represented the most frequently mutated genes in these studies ${ }^{3,4}$. The functional consequences of SF3B1 mutations, which have been associated with faster disease progression and poor overall survival (OS) in $\mathrm{CLL}^{5}$, and their near mutual exclusivity with $\mathrm{NOTCH} 1$ mutations $^{6}$ are also now better understood. The former, often associated with $\operatorname{del}(11 \mathrm{q})^{7}$, lead to alternative splicing $^{8,9}$, impairment of the DNA damage response network ${ }^{10}$, and dysregulation of NOTCH signaling and telomere biology ${ }^{11}$. In the German CLL8 trial that compared fludarabine, cyclophosphamide, and rituximab (FCR) with fludarabine and cyclophosphamide (FC) and showed a survival advantage for the chemoimmunotherapy (CIT) combination ${ }^{12}$, NOTCH1 mutations were associated with a lower rate of response to rituximab and the lack of a survival benefit from the addition of rituximab ${ }^{6}$. NOTCH1 mutations, which are most frequently present in CLL patients with trisomy $12^{13,14}$, have subsequently been shown to lead to epigenetic dysregulation, resulting in lower CD20 expression ${ }^{15}$. Del(13q), del(11q), trisomy 12, and mutations in the gene encoding MYD88, an adaptor protein in the Toll-like receptor pathway, appear to represent early genomic lesions with potential roles in CLL initiation, whereas mutations in SF3B1, the second allele of ATM and TP53 are likely to be later genetic events ${ }^{4,16}$.

TP53 mutations correlate strongly with del(17p $)^{6}$, just as ATM mutations do with del(11q) ${ }^{17}$. Though relatively infrequent in treatment-naïve CLL, TP53 mutations and deletions are significantly enriched for after CIT ${ }^{18}$. TP53 mutations are independently associated with worse progression-free survival (PFS) and OS in the setting of first-line $\mathrm{CIT}^{6}$ and have been incorporated into the recently published CLL-International Prognostic Index (CLL-IPI) ${ }^{19}$. This five-factor prognostic scoring system takes into account TP53 status (no abnormalities versus del(17p) or TP53 mutation or both), the mutational status of the immunoglobulin heavy chain variable region $(I G H V)$, age, clinical stage, and serum beta-2-microglobulin and discriminates between four risk groups with 5-year survival rates ranging from $23.3 \%$ to $93.2 \%{ }^{19}$. A simple and user-friendly "biomarkers-only" prognostic model using only $I G H V$ mutational status and cytogenetics by interphase fluorescence in situ hybridization was recently reported to perform as well as the CLL-IPI: in 524 unselected subjects with CLL, 10-year OS rates were $82 \%$ in the low-risk group, $52 \%$ in the intermediate-risk group, and $27 \%$ in the high-risk group; the model was validated in two independent cohorts, one of which was composed only of patients with Binet stage A CLL ${ }^{20}$. Efforts have also been made to integrate mutational and cytogenetic information into a genetic prognostic model for patients with CLL. This model, which remained valid at any time from diagnosis, delineated four risk groups with very different 10-year survival probabilities (29\%-69.3\%): high risk, comprising patients with TP53 or BIRC3 abnormalities or both; intermediate risk, characterized by NOTCH1 or $S F 3 B 1$ mutations or del(11q22-23) or a combination of these; low risk, consisting of patients with trisomy 12 or normal cytogenetics; and very low risk, patients with isolated del(13q14) $)^{21}$. Among patients with early-stage disease, high CLL-cell birth rates are associated with shorter treatment-free survival $^{22}$.

\section{Recent advances in targeting cell surface proteins}

The remarkable clinical benefits of the addition of rituximab (antiCD20 monoclonal antibody) to chemotherapy ${ }^{12,23}$ generated tremendous interest in this class of agents. Originally approved for the treatment of CLL refractory to both fludarabine and alemtuzumab, ofatumumab (Arzerra ${ }^{\circledR}$ ), a fully human anti-CD20 monoclonal antibody that binds to a different epitope than rituximab, has recently been approved, along with chlorambucil, for the first-line treatment of CLL in patients deemed unfit for fludarabine-based therapy, as monotherapy for the extended treatment ("maintenance") of patients with recurrent or progressive CLL who have received at least two lines of therapy and achieved a complete response (CR) or partial response (PR) to their most recent therapy, and in combination with FC for the treatment of patients with relapsed CLL, on the basis of the COMPLEMENT- ${ }^{24}$, PROLONG ${ }^{25}$, and COMPLEMENT- $2^{26}$ trials, respectively. However, because this agent has never been shown to be superior to rituximab in a head-to-head comparison, although such data exist for the type II glycoengineered anti-CD20 monoclonal antibody obinutuzumab (Gazyva $\left.{ }^{\mathrm{TM}}\right)^{27}$, and because of the advent of the new small-molecule targeted therapies, enthusiasm for the use of ofatumumab in CLL has waned considerably. Like obinutuzumab, ublituximab (formerly TG-1101) is an anti-CD20 monoclonal antibody with enhanced antibodydependent cellular cytotoxicity (ADCC); the lower fucose content of its $\mathrm{Fc}$ domain improves its binding to $\mathrm{Fc} \gamma \mathrm{RIIIA}^{28,29}$. In a phase $1 / 2$ trial in patients with rituximab-relapsed or -refractory B-cell nonHodgkin's lymphoma (NHL) $(n=27)$ or CLL $(n=8)$, the most common adverse events (AEs) were infusion-related reactions $(40 \%)$, fatigue (37\%), pyrexia (29\%), diarrhea (26\%), neutropenia (14\%), and anemia $(11 \%)^{30}$. In a phase 2 study in relapsed or refractory (R/R) 
CLL $(\mathrm{n}=45)$ in which patients received six cycles of ublituximab in conjunction with ibrutinib, the overall response rate (ORR) was $88 \%$ at 6 months $^{31}$. Among 20 patients with del(17p), del(11q), or TP53 mutation, the ORR was $95 \%$, and three of these patients attained minimal residual disease (MRD) negativity. This combination is now being compared with ibrutinib alone in the GENUINE phase 3 study (NCT02301156) in patients with R/R CLL bearing the above genetically high-risk features. At a median follow-up of 12 months, the best ORR by independent central review was $80 \%$ for ublituximab plus ibrutinib compared with $47 \%$ for ibrutinib alone ${ }^{32}$.

Otlertuzumab is a humanized, anti-CD37 monospecific protein therapeutic that has been studied in a phase 1 trial in 83 (mostly previously treated) patients with CLL ${ }^{33}$. Twelve (20\%) of sixtyone evaluable patients responded; all responses were partial and were more common in less heavily pretreated patients. This agent, in combination with bendamustine, has been compared with bendamustine alone in a small $(n=65)$ randomized phase 2 study in relapsed CLL ${ }^{34}$. ORRs were $69 \%$ in the combination arm and $39 \%$ for bendamustine alone $(P=0.025)$, which also translated into a PFS benefit (median of 15.9 versus 10.2 months, $P=0.0192$ ) for the combination. An ongoing phase 1b trial (NCT01644253) with many cohorts is studying this agent in combination with rituximab, obinutuzumab, ibrutinib, and idelalisib plus rituximab.

\section{Targeting Bruton's tyrosine kinase: ibrutinib and beyond}

The prototypical irreversible Bruton's tyrosine kinase (BTK) inhibitor ibrutinib is currently approved for all patients with CLL on the basis of the results of the RESONATE ${ }^{35}$, RESONATE- $2^{36}$, and RESONATE- $17^{37}$ trials. RESONATE compared ibrutinib with ofatumumab in 391 patients with R/R CLL or small lymphocytic lymphoma (SLL) and showed large improvements in ORRs and both PFS and $\mathrm{OS}^{35}$, as did RESONATE-2, which compared ibrutinib with chlorambucil in 269 treatment-naïve, older (at least 65 years of age) patients with CLL or SLL ${ }^{36}$. RESONATE-17 was a single-arm study of ibrutinib in 144 patients with R/R CLL or SLL and $\operatorname{del}(17 \mathrm{p})^{37}$. The ORR by independent review at the prespecified primary analysis after a median follow-up of 11.5 months was $64 \%(83 \% \text { by investigator assessment })^{37}$. After a median followup of 27.6 months $(\mathrm{n}=120)$, the investigator-assessed ORR was $83 \%, 24$-month PFS was $63 \%$, and 24 -month OS was $75 \%{ }^{37}$. Of note, complex karyotype may be a stronger predictor of inferior outcomes than del(17p) among patients with R/R CLL in the setting of ibrutinib therapy ${ }^{38}$; however, not all studies have arrived at similar conclusions ${ }^{39}$. Overall, responses to ibrutinib are durable and improve over time, while toxicities such as treatment-emergent grade $3 / 4$ cytopenias, fatigue, and infections diminish ${ }^{40}$. Disease progression is uncommon up to three years (median) of followup and mainly occurs in patients with relapsed disease harboring $\operatorname{del}(17 p)$ or $\operatorname{del}(11 q)^{40}$.

While ibrutinib's mobilizing effects on CLL cells resident in protective nodal microenvironmental niches and interference with their homing to the same are well known ${ }^{41}$, an elegant study using deuterated water labeling has shown that the drug also has profound and immediate anti-proliferative and apoptosis-inducing actions on
CLL cells ${ }^{42}$. Ibrutinib is more efficient at clearing lymph node than blood or marrow disease, and recent work has demonstrated that the highest rate of CLL cell proliferation occurs in the lymph nodes ${ }^{43}$. However, the "redistribution lymphocytosis" caused by ibrutinib, which has led to the introduction of the CLL response category "partial response with lymphocytosis $\left(\mathrm{PR}_{\mathrm{L}}\right)$ " 44 , does not have any adverse long-term consequences even if prolonged, and these cells eventually die from the lack of microenvironmental pro-survival signals $^{45}$.

\section{Ibrutinib resistance and therapeutic options}

Resistance to ibrutinib has been attributed to acquired mutations in BTK that only allow the kinase to be reversibly bound by ibrutinib, as well as downstream mutations in phospholipase $\mathrm{C}$ gamma 2 $(\mathrm{PLC} \gamma 2)$ that reactivate $\mathrm{B}$-cell receptor (BCR) signaling despite inhibition of BTK function by ibrutinib ${ }^{46-48}$. More recent work has identified clonal evolution, particularly the emergence of $\operatorname{del}(8 \mathrm{p})$ clones harboring additional driver mutations (in EP300, $M L L 2$, and EIF2A), as an additional mechanism of development of resistance to ibrutinib ${ }^{49}$. Outcomes after ibrutinib discontinuation have been reported to be poor ${ }^{50,51}$, particularly for patients discontinuing because of progression and especially Richter's transformation (RT) of their CLL, but appear to be improving with the availability of newer and effective salvage options ${ }^{52}$. RTs usually occur early, whereas CLL progressions generally tend to be later events $^{51}$. Clinical data are available supporting the efficacy of commercially available drugs such as idelalisib and venetoclax in the setting of ibrutinib resistance or intolerance (discussed below) ) $^{53,54}$ as well as investigational agents such as duvelisib (formerly IPI145, discussed below) ${ }^{55}$ and entospletinib (formerly GS-9973, a spleen tyrosine kinase inhibitor $)^{56}$.

Additionally, protein kinase $\mathrm{C}$ beta inhibitors ${ }^{57}$, heat shock protein 90 inhibitors $^{58}$, and selective inhibitors of nuclear export ${ }^{59}$ hold promise in preclinical studies to overcome ibrutinib resistance in CLL. Finally, a number of reversible BTK inhibitors that bind outside of the $\mathrm{C} 481$ residue targeted by ibrutinib and therefore are able to effectively inhibit the resistant $\mathrm{C} 481 \mathrm{~S}$ mutant are in development ${ }^{60-62}$.

\section{Other Bruton's tyrosine kinase inhibitors}

Ibrutinib inhibits a number of kinases besides BTK, its primary therapeutic target in $\mathrm{CLL}^{63}$, including some at subnanomolar concentrations ${ }^{64}$. Some of these off-target effects of ibrutinib may be responsible for some of its unique toxicities (for example, atrial fibrillation ${ }^{65}$ and bleeding ${ }^{66-68}$ ). Thus, there is considerable interest in developing more selective inhibitors of BTK. Among these, acalabrutinib (formerly ACP-196) is farthest along in clinical development (phase 3). Consistent with the concept that acalabrutinib is a more selective BTK inhibitor, preclinical studies have demonstrated that ibrutinib and acalabrutinib have similar biological activity in primary CLL cells but appear to have differences in their impact on normal $\mathrm{T}$ cells ${ }^{69}$. In a phase $1-2$ study in 61 patients with relapsed CLL and a median of three prior therapies, acalabrutinib produced an ORR of $95 \%\left(85 \% \mathrm{PR}\right.$ and $\left.10 \% \mathrm{PR}_{\mathrm{L}}\right)$; all patients with $\operatorname{del}(17 \mathrm{p})$ responded $^{70}$. In a phase 1 trial of another selective BTK inhibitor, ONO/GS-4059, in 90 patients with R/R B-cell malignancies, $24(96 \%)$ of 25 evaluable patients with CLL responded, and 
the median duration of response was 80 weeks $^{71}$. Yet another such agent is BGB-3111 ${ }^{72}$. The ORR to this agent among 29 evaluable patients with R/R CLL/SLL was $90 \%\left(79 \% \mathrm{PR} \text { and } 10 \% \mathrm{PR}_{\mathrm{L}}\right)^{73}$. With the short follow-up reported thus far, all three agents have been very well tolerated; however, there have been cases of major bleeding and atrial fibrillation reported with ONO/GS-4059 and BGB-3111 71,73 .

\section{Ibrutinib dose and biological activity}

Another approach to minimize the off-target toxicities of ibrutinib while preserving efficacy may be the exploration of lower doses $^{74}$. This is based on the observations that ibrutinib doses of at least $2.5 \mathrm{mg} / \mathrm{kg}$ per day were sufficient to achieve at least $95 \%$ BTK occupancy in the phase 1 trial in patients with R/R B-cell malignancies $^{75}$ and that BTK levels decline over time in CLL cells from ibrutinib-treated patients ${ }^{76,77}$. Since ibrutinib is an irreversible inhibitor of BTK and binds to BTK in a 1:1 stoichiometric ratio, this would imply the need for lower doses of ibrutinib over time as BTK levels decline. Therefore, continued dosing at $420 \mathrm{mg} /$ day could lead to greater off-target binding and toxicity ${ }^{74}$. Our group is currently studying the pharmacodynamic correlates, including BTK occupancy, of progressively lower dosing of ibrutinib in patients with CLL in the context of a pilot study (NCT02801578). Importantly, a retrospective multi-institutional "real world" study published recently showed that reduced dose ibrutinibdefined as sustained (for at least 2 months) dosing at less than $420 \mathrm{mg} /$ day, either at treatment initiation or within 3 months from starting ibrutinib - did not compromise outcomes (that is, ORR or PFS $)^{78}$. Toxicity or physician preference drove the decision to reduce the dose of ibrutinib in the vast majority of cases. In contrast, missing at least 8 consecutive days of ibrutinib has been correlated with shorter median PFS ${ }^{79}$.

\section{Combination strategies involving ibrutinib}

Ibrutinib has been combined with anti-CD20 monoclonal antibodies in non-comparative clinical trials ${ }^{80,81}$, and although early fears of antagonism of rituximab-mediated ADCC by ibrutinib based on preclinical studies ${ }^{82}$ have been laid to rest, the incremental benefit of this approach (versus ibrutinib alone) is not clear. Similarly, the HELIOS study in 578 patients with R/R non-del(17p) CLL or SLL showed improved PFS with the addition of ibrutinib to bendamustine and rituximab (BR), but this regimen does not appear to offer meaningful advantages over ibrutinib monotherapy, except when a rapid response is clinically desirable ${ }^{83}$. One US cooperative group study is investigating BR, ibrutinib alone, or ibrutinib plus rituximab in previously untreated patients at least 65 years of age (NCT01886872), while another is comparing frontline FCR with ibrutinib plus rituximab in patients 18 to 70 years of age (NCT02048813). Accrual to both of these studies is complete and results are awaited.

\section{Targeting phosphatidylinositol-3-kinase: idelalisib and newer inhibitors}

Idelalisib

The first-in-class phosphatidylinositol-3-kinase (PI3K) delta isoform-specific inhibitor idelalisib (Zydelig ${ }^{\circledR}$ ) was approved in conjunction with rituximab by the US Food and Drug Administration (FDA) in 2014 for patients with relapsed CLL for whom rituximab alone would be considered appropriate therapy (because of co-morbidities) on the basis of the results of a pivotal phase 3 study in which the combination significantly improved both PFS and OS over rituximab plus placebo, so much so that the trial was stopped early ${ }^{84}$. Like ibrutinib, idelalisib blocks signaling through the BCR pathway and is efficacious in patients harboring $\operatorname{del}(17 \mathrm{p})$ or TP53 aberrations. We have recently shown that in mantle cell lymphoma cell lines and patient-derived samples, idelalisib inhibits protein synthesis, which correlates with reductions in AKT (the immediate downstream effector of PI3K) and mitogenactivated protein kinase kinase (MEK) phosphorylation ${ }^{85}$. Idelalisib synergizes with bendamustine in primary CLL cells, increasing DNA damage and suppressing transcription of the antiapoptotic protein myeloid cell leukemia 1 (MCL-1 $)^{86}$. Indeed, in a recently reported phase 3 trial $(n=416)$, the combination of idelalisib with BR markedly enhanced PFS in patients with R/R CLL (median of 20.8 versus 11.1 months for BR plus placebo after a median follow-up of 14 months $)^{87}$. Idelalisib plus ofatumumab has also been compared with ofatumumab alone in 261 patients with R/R CLL (median number of prior therapies $=3$ ) in a randomized phase 3 trial $^{88}$. The primary analysis of this trial showed a doubling of median PFS (16.3 versus 8 months) in the combination arm.

The use of idelalisib in patients with CLL has been constrained by toxicity concerns, particularly given the superior safety profile of ibrutinib. The US prescribing information for idelalisib contains a black-box warning for fatal or serious hepatotoxicity or both (11\%-18\%), diarrhea/colitis (14\%-19\%), pneumonitis (4\%), infections $(21 \%-36 \%)$, and intestinal perforation, and a high degree of vigilance for these AEs is essential in patients receiving idelalisib. The incidence of hepatotoxicity, believed to be immune-mediated, has been reported to be particularly high in the setting of frontline idelalisib monotherapy; 19 (79\%) of 24 subjects experienced some degree of transaminitis and $13(54 \%)$ had at least grade 3 transaminitis in a recent study ${ }^{89}$. The median time to development of transaminitis was 28 days, and younger age and mutated $I G H V$ status predicted for this complication. Very recently, it was reported that PI3K delta blockade by either idelalisib or duvelisib (discussed below), through upregulation of the B cell-specific enzyme activation-induced cytidine deaminase, induces genomic instability in normal and neoplastic B cells, which could lead to lymphomagenesis given the potential for patients to be on these drugs for prolonged periods ${ }^{90}$.

\section{Other PI3K inhibitors}

TGR-1202 is a novel PI3K delta inhibitor with an improved safety profile, particularly with regard to hepatotoxicity and colitis. In a phase 1 study in patients with R/R CLL or NHL, 10 (63\%) of 16 evaluable patients with CLL achieved a PR. This agent has been combined with ublituximab: of $10 \mathrm{R} / \mathrm{R}$ CLL patients who received the combination, all were progression-free at a median of 8 months when these data were last presented. A pivotal phase 3 trial (UNITY-CLL) comparing ublituximab and TGR-1202 with chlorambucil and obinutuzumab is under way (NCT02612311), as are a number of other studies combining TGR-1202 or TGR-1202 plus ublituximab with ibrutinib, bendamustine, or pembrolizumab. 
Duvelisib (reviewed in 91) is a small-molecule inhibitor of both the delta and gamma isoforms of PI3K that potently and selectively inhibits the proliferation of primary CLL cells, induces apoptosis, and interferes with the homing capabilities of CLL cells through blockade of BCR signaling ${ }^{92}$. Preclinically, duvelisib impairs the viability of $\mathrm{T}$ cells and natural killer cells and decreases the production by activated $\mathrm{T}$ cells of inflammatory and anti-apoptotic cytokines ${ }^{93}$. ORRs to single-agent duvelisib have ranged from $55 \%$ in heavily pretreated patients with R/R CLL to $82 \%$ in previously untreated patients; as with ibrutinib and idelalisib, the vast majority of responses have been partial ${ }^{94,95}$. Duvelisib has been studied in combination with bendamustine, rituximab, and BR in patients with R/R CLL or indolent NHL with good tolerability ${ }^{96}$. In treatment-naïve patients, the addition of duvelisib to FCR appears to substantially increase the rate of MRD negativity ${ }^{97}$, a strong surrogate for long-term outcome in CLL ${ }^{98}$. Results of the completed phase 3 DUO study (NCT02004522) comparing duvelisib with ofatumumab in 319 patients with R/R CLL or SLL are expected soon; the trial has met its primary endpoint of significantly improved PFS in the duvelisib arm (13.3 versus 9.9 months), according to topline results released recently by the company.

\section{Targeting B-cell lymphoma 2 with venetoclax}

CLL cells are exquisitely dependent on the B-cell lymphoma 2 (BCL-2) anti-apoptotic protein for survival"9, and the "BH3mimetic" navitoclax, an antagonist of both BCL-2 and BCL-xL, showed promising activity in patients with $\mathrm{R} / \mathrm{R} \mathrm{CLL}^{100}$, but the development of this agent was hampered by the occurrence of dose-limiting thrombocytopenia in all clinical trials, an on-target consequence of the drug's action on platelets and megakaryocytes, which rely on BCL-xL for survival ${ }^{101}$. These observations led to the development of venetoclax (Venclexta ${ }^{\mathrm{TM}}$, formerly ABT-199), a highly BCL-2-selective antagonist that spares platelets ${ }^{102}$, by reverse engineering of navitoclax.

In a phase 1 trial with dose escalation and expansion phases, 116 patients with R/R CLL or SLL (but none previously treated with BCR inhibitors) received venetoclax ${ }^{103}$. The ORR was $79 \%$, including CRs in $20 \%$ of patients, a quarter of which were MRD-negative. Clinical tumor lysis syndrome (TLS), fatal in one case, occurred in three of 56 patients in the dose escalation phase, but did not recur in the dose expansion phase $(n=60)$, after a careful dose rampup to a maximum of $400 \mathrm{mg}$ daily was instituted. Mild diarrhea $(52 \%)$, upper respiratory infection $(48 \%)$, nausea $(47 \%)$, and grade $3 / 4$ neutropenia $(41 \%)$ were frequent. Venetoclax was approved in 2016 by the FDA for patients with CLL with del(17p) based on an ORR of $79.4 \%$ in a separate study $(n=107)$ carried out exclusively in patients with $\mathrm{R} / \mathrm{R} \operatorname{del}(17 \mathrm{p}) \mathrm{CLL}^{104}$. The CR rate, with or without complete count recovery, in this study was only $8 \%$, and only $5 \%$ of the patients had received prior BCR inhibitors. Grade 3/4 neutropenia was very common (40\%), and grade $3 / 4$ infections, anemia, and thrombocytopenia occurred in $20 \%, 18 \%$, and $15 \%$ of patients, respectively. According to the current label, the dose of venetoclax should be ramped up over a 4- to 5-week period from 20 to $400 \mathrm{mg}$ daily to minimize the risk of TLS. Venetoclax was combined with rituximab in a phase 1 trial in 49 patients with $R / R$ CLL or SLL, and the recommended phase 2 dose (RP2D) was found to be $400 \mathrm{mg} /$ day in this setting as well ${ }^{105}$. Clinical TLS occurred in two patients who started the dose ramp-up at $50 \mathrm{mg} / \mathrm{day}$, and resulted in one death. The ORR was $86 \%$ and MRD negativity was attained in $57 \%$. Twenty-five patients $(51 \%)$ achieved CR and 20 of them (80\%) were MRD-negative. Grade 1/2 upper respiratory infection, diarrhea, and nausea were very frequent, affecting $57 \%, 55 \%$, and $51 \%$ of patients, respectively. Grade 3/4 neutropenia affected $53 \%$ of patients, and febrile neutropenia $12 \%$; $14 \%$ and $16 \%$ of patients, respectively, had grade $3 / 4$ anemia and thrombocytopenia.

An important question not addressed by the above studies concerns the efficacy of venetoclax in patients failing BCR inhibitors. This is the subject of an ongoing study, preliminary results of which have been presented ${ }^{53}$. The study enrolled only patients who had relapsed or were refractory to ibrutinib $(n=43)$ or idelalisib $(\mathrm{n}=21)$. The ORRs to venetoclax monotherapy were $70 \%$ in the prior ibrutinib group and $48 \%$ in the prior idelalisib group. Only one CR (with incomplete count recovery) was documented by independent review-in the prior ibrutinib group.

\section{Combination strategies and the road to a cure in chronic lymphocytic leukemia}

Long-term (more than 10 years) relapse-free remissions are already achievable with FCR in the subset of patients with favorable genomic prognostic factors (that is, mutated $I G H V$, del(13q), normal cytogenetics, or trisomy 12$)^{106}$. Ongoing clinical trials are attempting to further improve outcomes by adding ibrutinib to frontline FCR, followed by ibrutinib maintenance in younger, fit patients ${ }^{107}$, or adding ibrutinib and replacing rituximab with the more potent obinutuzumab, while reducing the exposure to cytotoxic chemotherapy (to mitigate the real risk of therapyrelated myeloid neoplasms $)^{108}$, as well as limiting the duration of ibrutinib maintenance using an MRD-driven approach in previously untreated patients with mutated $I G H V$ and without $\operatorname{del}(17 p)^{109}$. Achievement of MRD negativity has become widely established as a necessary first step to an eventual cure of CLL (reviewed in 110).

Preclinical studies from our group ${ }^{111}$ and others ${ }^{112}$ have demonstrated synergism between ibrutinib and venetoclax in CLL. The clinical efficacy profiles of these two oral agents also complement each other well, as ibrutinib is particularly effective at clearing nodal disease and less so at clearing marrow disease, whereas venetoclax has the opposite profile and also does not cause the redistribution lymphocytosis typical of BCR inhibitors. Furthermore, $\mathrm{CR}$ rates with ibrutinib monotherapy, at least in the R/R setting, are very low ${ }^{35,113}$ and clearly better with venetoclax, which is additionally capable of inducing MRD negativity on its own ${ }^{103}$. These observations make this a particularly attractive combination, which is being studied in several ongoing clinical trials in both the frontline and R/R settings (NCT02756897, NCT03045328, and NCT02910583). Other trials are studying the triple combination of ibrutinib, venetoclax, and obinutuzumab (NCT02758665 and NCT02427451). Early results demonstrate tolerability of the triple combination, and the RP2D of venetoclax is the same as the approved monotherapy dose (that is, $400 \mathrm{mg} / \mathrm{day})^{114}$. Aside from toxicity concerns, the enormous economic burden of indefinite therapy of CLL with the new oral targeted agents ${ }^{115}$ makes 
achievement of a deep response with the use of an optimal combination regimen for a finite duration with, hopefully, a durable treatment-free remission an important goal.

Duvelisib has also been shown to synergize with venetoclax in induction of apoptosis of CLL cells ${ }^{116}$. However, there are no ongoing clinical studies of PI3K delta inhibitors in combination with venetoclax; one involving duvelisib was withdrawn. This could reflect the substantial toxicity concerns with idelalisib discussed above, as well as the recent findings of induction of genomic instability in B cells by both idelalisib and duvelisib ${ }^{90}$. If indeed TGR1202 turns out to have a much improved safety profile in the clinic, it is possible that the combination of this agent with venetoclax will be pursued in trials.

\section{Emerging drug targets}

Single-agent immune checkpoint blockade with pembrolizumab (Keytruda ${ }^{\circledR}$ ), a monoclonal antibody directed against programmed death 1 (PD-1), was recently shown to have substantial clinical activity in patients with RT, a difficult-to-treat, poor-prognosis entity, but not in CLL ${ }^{117}$. As noted above, this agent is also being studied in combination with ublituximab plus TGR-1202 in patients with R/R CLL or RT (NCT02535286). Additionally, it is being evaluated in combination with ibrutinib or idelalisib in patients with R/R CLL (NCT02332980). The anti-PD-1 monoclonal antibody nivolumab (Opdivo ${ }^{\circledR}$ ) is also being evaluated in combination with ibrutinib in both patients with RT and R/R or high-risk CLL (NCT02420912). Studies in mouse models of lymphoma support the combination of ibrutinib with immune checkpoint blockade $^{118}$. This is based, in part, on the inhibition by ibrutinib of interleukin-2-inducible kinase (ITK) in T cells, which skews T-cell immune responses away from Th2 and toward a Th1 phenotype $^{119}$.

Resistance to venetoclax is largely driven by MCL-1 (reviewed in 120); for years, this anti-apoptotic protein has eluded therapeutic targeting. However, a number of clinical candidate compounds capable of directly antagonizing the function of MCL-1 are now on the horizon ${ }^{121-123}$ and hopefully will be available in the future for combination with venetoclax. Furthermore, therapy with BCR axis inhibitors such as ibrutinib ${ }^{111}$, acalabrutinib ${ }^{69}$, idelalisib ${ }^{124}$, and duvelisib $^{116}$ results in a decline in MCL-1 protein levels in CLL cells, providing a mechanism-based rationale to combine them with venetoclax. Another strategy involves downregulating this shortlived anti-apoptotic protein through transcriptional repression, achievable by inhibition of cyclin-dependent kinase 9 (CDK9 $)^{125}$.
While "pan"-CDK inhibitors have displayed clear evidence of activity in CLL ${ }^{126,127}$, current efforts in this area are focusing on developing agents that are selective for CDK9. CYC065, for example, is highly selective for CDK2 and CDK9.

A relatively new therapeutic target in CLL is colony-stimulating factor 1R (CSF1R), expressed on tumor-associated macrophages (TAMs), and macrophage killing by CSF1R blockade induces CLL cell death, primarily through the tumor necrosis factor pathway $^{128}$. TAMs provide support to CLL cells via a PI3K-AKTmammalian target of rapamycin (mTOR)-dependent translational upregulation of $\mathrm{MCL}-1^{129}$. Both small-molecule kinase inhibitors (for example, pexidartinib ${ }^{130}$ and BLZ945 ${ }^{131}$ ) and monoclonal antibodies targeting CSF1R are in development for various tumor types.

\section{Conclusions}

The past few years have seen enormous advancements in our understanding of CLL biology and drug discovery and clinical development. The advent of the BCR inhibitors and venetoclax has fundamentally changed the paradigm of CLL management and brought unprecedented benefits to patients, particularly those with historically poor outcomes with CIT (for example, those with $\operatorname{del}(17 \mathrm{p})$ or TP53 abnormalities). The challenges facing the field in the coming years will be how to optimally combine and sequence these and newer agents so as to achieve high rates of MRD eradication, hopefully enabling treatment discontinuation and translating to long-term relapse-free survival. Identification of mechanisms of resistance to the novel targeted agents and their abrogation, along with effective treatment and prevention of RT, will likely become a major focus of CLL research in the years to come. New drugs targeted against CD37, MCL-1, CDK9, CSF1R, and so on hold promise for an even more robust therapeutic armamentarium in the near future.

\section{Competing interests}

Relevant to this manuscript, Prithviraj Bose has nothing to disclose and Varsha Gandhi has received research grants from AbbVie, Acerta, Gilead, Infinity, Pharmacyclics, and Sunesis.

\section{Grant information}

The authors declared that this work was funded by National Institutes of Health (grants P30 CA016672), MD Anderson's CLL Moon shot program, and a CLL-GRF Alliance grant.
1. Tausch $E$, Mertens $D$, Stilgenbauer S: Advances in treating chronic lymphocytic leukemia. F1000Prime Rep. 2014; 6: 65 PubMed Abstract | Publisher Full Text | Free Full Text

2. Lazarian G, Guièze R, Wu CJ: Clinical Implications of Novel Genomic Discoveries in Chronic Lymphocytic Leukemia. J Clin Oncol. 2017; 35(9): 984-93. PubMed Abstract | Publisher Full Text | Free Full Text

3. F Puente XS, Beà S, Valdés-Mas R, et al:: Non-coding recurrent mutations in chronic lymphocytic leukaemia. Nature. 2015: 526(7574): 519-24. PubMed Abstract | Publisher Full Text | F1000 Recommendation

4. F Landau DA, Tausch E, Taylor-Weiner AN, et al: Mutations driving CLL and their evolution in progression and relapse. Nature. 2015; 526(7574): 525-30. PubMed Abstract | Publisher Full Text | Free Full Text | F1000 Recommendation

5. Quesada V, Conde L, Villamor N, et al:: Exome sequencing identifies recurrent mutations of the splicing factor SF3B1 gene in chronic lymphocytic leukemia. 
Nat Genet. 2011; 44(1): 47-52.

PubMed Abstract | Publisher Full Text

6. Stilgenbauer S, Schnaiter A, Paschka P, et al:: Gene mutations and treatment outcome in chronic lymphocytic leukemia: results from the CLL8 trial. Blood. 2014; 123(21): 3247-54.

PubMed Abstract | Publisher Full Text

7. $\quad F$ Wang L, Lawrence MS, Wan $Y$, et al:: SF3B1 and other novel cancer genes in chronic lymphocytic leukemia. N Engl J Med. 2011; 365(26): 2497-506. PubMed Abstract | Publisher Full Text | Free Full Text | F1000 Recommendation

8. Darman RB, Seiler M, Agrawal AA, et al:: Cancer-Associated SF3B1 Hotspot Mutations Induce Cryptic 3' Splice Site Selection through Use of a Different Branch Point. Cell Rep. 2015; 13(5): 1033-45.

PubMed Abstract | Publisher Full Text

9. DeBoever C, Ghia EM, Shepard PJ, et al.: Transcriptome sequencing reveals potential mechanism of cryptic 3' splice site selection in SF3B1-mutated cancers. PLOS Comput Biol. 2015; 11(3): e1004105 PubMed Abstract | Publisher Full Text | Free Full Text

10. Te Raa GD, Derks IA, Navrkalova V, et al: The impact of SF3B1 mutations in CLL on the DNA-damage response. Leukemia. 2015; 29(5): 1133-42. PubMed Abstract | Publisher Full Text

11. Wang L, Brooks AN, Fan J, et al.: Transcriptomic Characterization of SF3B1 Mutation Reveals Its Pleiotropic Effects in Chronic Lymphocytic Leukemia. Cancer Cell. 2016; 30(5): 750-63.

PubMed Abstract | Publisher Full Text | Free Full Text

12. Hallek M, Fischer K, Fingerle-Rowson G, et al:: Addition of rituximab to fludarabine and cyclophosphamide in patients with chronic lymphocytic leukaemia: a randomised, open-label, phase 3 trial. Lancet. 2010; 376(9747): 1164-74.

PubMed Abstract | Publisher Full Tex

13. Balatti V, Bottoni A, Palamarchuk A, et al.: NOTCH1 mutations in CLL associated with trisomy 12. Blood. 2012; 119(2): 329-31.

PubMed Abstract | Publisher Full Text | Free Full Text

14. Riches JC, O'Donovan CJ, Kingdon SJ, et al:: Trisomy 12 chronic lymphocytic leukemia cells exhibit upregulation of integrin signaling that is modulated by NOTCH1 mutations. Blood. 2014; 123(26): 4101-10. PubMed Abstract | Publisher Full Text | Free Full Text

15. Pozzo F, Bittolo T, Arruga F, et al.: NOTCH1 mutations associate with low CD20 level in chronic lymphocytic leukemia: evidence for a NOTCH1 mutation-driven epigenetic dysregulation. Leukemia. 2016; 30(1): 182-9. PubMed Abstract | Publisher Full Text

16. Landau DA, Carter SL, Stojanov P, et al.: Evolution and impact of subclona mutations in chronic lymphocytic leukemia. Cell. 2013; 152(4): 714-26. PubMed Abstract | Publisher Full Text | Free Full Text

17. Austen B, Skowronska A, Baker C, et al: Mutation status of the residual ATM allele is an important determinant of the cellular response to chemotherapy and survival in patients with chronic lymphocytic leukemia containing an 11q deletion. J Clin Oncol. 2007; 25(34): 5448-57. PubMed Abstract | Publisher Full Tex

18. Edelmann J, Tausch E, Landau DA, et al.: Frequent evolution of copy number alterations in CLL following first-line treatment with $\mathrm{FC}(\mathrm{R})$ is enriched with TP53 alterations: results from the CLL8 trial. Leukemia. 2017; 31(3): 734-8. PubMed Abstract | Publisher Full Text | Free Full Text

19. International CLL-IPI working group: An international prognostic index for patients with chronic lymphocytic leukaemia (CLL-IPI): a meta-analysis of individual patient data. Lancet Oncol. 2016; 17(6): 779-90. PubMed Abstract | Publisher Full Text

20. F Delgado J, Doubek M, Baumann T, et al.: Chronic lymphocytic leukemia: A prognostic model comprising only two biomarkers (IGHV mutational status and FISH cytogenetics) separates patients with different outcome and simplifies the CLL-IPI. Am J Hematol. 2017; 92(4): 375-80. PubMed Abstract | Publisher Full Text | F1000 Recommendation

21. Rossi D, Rasi S, Spina V, et al:: Integrated mutational and cytogenetic analysis identifies new prognostic subgroups in chronic lymphocytic leukemia. Blood. 2013; 121(8): 1403-12.

PubMed Abstract | Publisher Full Text | Free Full Text

22. F Murphy EJ, Neuberg DS, Rassenti LZ, et al: Leukemia-cell proliferation and disease progression in patients with early stage chronic lymphocytic leukemia. Leukemia. 2017; 31(6): 1348-54.

PubMed Abstract | Publisher Full Text | Free Full Text | F1000 Recommendation

23. Keating MJ, O'Brien S, Albitar M, et al.: Early results of a chemoimmunotherapy regimen of fludarabine, cyclophosphamide, and rituximab as initial therapy for chronic lymphocytic leukemia. J Clin Oncol. 2005; 23(18): 4079-88. PubMed Abstract | Publisher Full Text

24. Hillmen $\mathrm{P}$, Robak $\mathrm{T}$, Janssens $\mathrm{A}$, et al.: Chlorambucil plus ofatumumab versus chlorambucil alone in previously untreated patients with chronic lymphocytic leukaemia (COMPLEMENT 1): a randomised, multicentre, open-label phase 3 trial. Lancet. 2015; 385(9980): 1873-83. PubMed Abstract | Publisher Full Tex

25. van Oers $\mathrm{MH}$, Kuliczkowski $\mathrm{K}$, Smolej $\mathrm{L}$, et al:: Ofatumumab maintenance versus observation in relapsed chronic lymphocytic leukaemia (PROLONG): an open-label, multicentre, randomised phase 3 study. Lancet Oncol. 2015; 16(13): $1370-9$.

PubMed Abstract | Publisher Full Text
26. Robak T, Warzocha K, Govind Babu K, et al:: Ofatumumab plus fludarabine and cyclophosphamide in relapsed chronic lymphocytic leukemia: results from the COMPLEMENT 2 trial. Leuk Lymphoma. 2017; 58(5): 1084-93.

PubMed Abstract | Publisher Full Text

27. F Goede V, Fischer K, Busch R, et al:: Obinutuzumab plus chlorambucil in patients with CLL and coexisting conditions. N Engl J Med. 2014; 370(12): 1101-10.

PubMed Abstract | Publisher Full Text | F1000 Recommendation

28. de Romeuf C, Dutertre CA, Le Garff-Tavernier M, et al.: Chronic lymphocytic leukaemia cells are efficiently killed by an anti-CD20 monoclonal antibody selected for improved engagement of FcgammaRIIIA/CD16. Br J Haematol. 2008; 140(6): 635-43.

PubMed Abstract | Publisher Full Text

29. Le Garff-Tavernier M, Herbi L, de Romeuf C, et al.: Antibody-dependent cellular cytotoxicity of the optimized anti-CD20 monoclonal antibody ublituximab on chronic lymphocytic leukemia cells with the 17p deletion. Leukemia. 2014; 28(1): 230-3. PubMed Abstract | Publisher Full Tex

30. F Sawas A, Farber CM, Schreeder MT, et al: A phase 1/2 trial of ublituximab a novel anti-CD20 monoclonal antibody, in patients with B-cell non-Hodgkin ymphoma or chronic lymphocytic leukaemia previously exposed to rituximab. Br J Haematol. 2017; 177(2): 243-53.

PubMed Abstract | Publisher Full Text | Free Full Text | F1000 Recommendation

31. F Sharman JP, Farber CM, Mahadevan D, et al:: Ublituximab (TG-1101), a novel glycoengineered anti-CD20 antibody, in combination with ibrutinib is safe and highly active in patients with relapsed and/or refractory chronic lymphocytic leukaemia: results of a phase 2 trial. Br J Haematol. 2017; 176(3): lymphoc $412-20$.

PubMed Abstract | Publisher Full Text | Free Full Text | F1000 Recommendation

32. Sharman JP, Brander DM, Mato A, et al:: Ublituximab and ibrutinib for previously treated genetically high-risk chronic lymphocytic leukemia: results of the genuine phase 3 study. Hematol Oncol. 2017; 35(Supplement S2): 111-2. Publisher Full Text

33. Byrd JC, Pagel JM, Awan FT, et al:: A phase 1 study evaluating the safety and tolerability of otlertuzumab, an anti-CD37 mono-specific ADAPTIR therapeutic protein in chronic lymphocytic leukemia. Blood. 2014; 123(9): 1302-8. PubMed Abstract | Publisher Full Text | Free Full Text

34. F Robak T, Hellmann A, Kloczko J, et al:: Randomized phase 2 study of otlertuzumab and bendamustine versus bendamustine in patients with relapsed chronic lymphocytic leukaemia. Br J Haematol. 2017; 176(4): 618-28. PubMed Abstract | Publisher Full Text | Free Full Text | F1000 Recommendation

35. F Byrd JC, Brown JR, O'Brien S, et al.: Ibrutinib versus ofatumumab in previously treated chronic lymphoid leukemia. N Engl J Med. 2014; 371(3): 213-23.

PubMed Abstract | Publisher Full Text | Free Full Text | F1000 Recommendation

36. F Burger JA, Tedeschi A, Barr PM, et al:: Ibrutinib as Initial Therapy for Patients with Chronic Lymphocytic Leukemia. N Engl J Med. 2015; 373(25): 2425-37.

PubMed Abstract | Publisher Full Text | Free Full Text | F1000 Recommendation

37. F O'Brien S, Jones JA, Coutre SE, et al:: Ibrutinib for patients with relapsed or refractory chronic lymphocytic leukaemia with 17p deletion (RESONATE-17): a phase 2, open-label, multicentre study. Lancet Oncol. 2016; 17(10): 1409-18. PubMed Abstract | Publisher Full Text | F1000 Recommendation

38. Thompson PA, O'Brien SM, Wierda WG, et al:: Complex karyotype is a stronger predictor than del(17p) for an inferior outcome in relapsed or refractory chronic lymphocytic leukemia patients treated with ibrutinib-based regimens. Cancer. 2015; 121(20): 3612-21.

PubMed Abstract | Publisher Full Text | Free Full Text

39. O'Brien SM, Furman RR, Coutre SE, et al.: Five-Year Experience with SingleAgent Ibrutinib in Patients with Previously Untreated and Relapsed/Refractory Chronic Lymphocytic Leukemia/Small Lymphocytic Leukemia. Blood. 2016; 128: 233.

Reference Source

40. Byrd JC, Furman RR, Coutre SE, et al.: Three-year follow-up of treatment-naïve and previously treated patients with CLL and SLL receiving single-agent brutinib. Blood. 2015; 125(16): 2497-506. PubMed Abstract | Publisher Full Text | Free Full Text

41. Burger JA, Montserrat $E$ : Coming full circle: 70 years of chronic lymphocytic leukemia cell redistribution, from glucocorticoids to inhibitors of B-cell receptor signaling. Blood. 2013; 121(9): 1501-9. PubMed Abstract | Publisher Full Text | Free Full Text

42. F Burger JA, Li KW, Keating MJ, et al.: Leukemia cell proliferation and death in chronic lymphocytic leukemia patients on therapy with the BTK inhibitor ibrutinib. JCl Insight. 2017; 2(2): e89904. PubMed Abstract | Publisher Full Text | Free Full Text | F1000 Recommendation

43. $\mathrm{F}$ Herndon TM, Chen SS, Saba NS, et al:: Direct in vivo evidence for increased proliferation of CLL cells in lymph nodes compared to bone marrow and peripheral blood. Leukemia. 2017; 31(6): 1340-7.

PubMed Abstract | Publisher Full Text | Free Full Text | F1000 Recommendation 4. Cheson BD, Byrd JC, Rai KR, et al.: Novel targeted agents and the need to refine clinical end points in chronic lymphocytic leukemia. J Clin Oncol. 2012; 30(23): 
2820-2.

PubMed Abstract | Publisher Full Text | Free Full Text

45. F Woyach JA, Smucker K, Smith LL, et al:: Prolonged lymphocytosis during ibrutinib therapy is associated with distinct molecular characteristics and does not indicate a suboptimal response to therapy. Blood. 2014; 123(12): 1810-7.

PubMed Abstract | Publisher Full Text | Free Full Text | F1000 Recommendation

46. Woyach JA, Furman RR, Liu TM, et al.: Resistance mechanisms for the Bruton's tyrosine kinase inhibitor ibrutinib. N Engl J Med. 2014; 370(24): 2286-94. PubMed Abstract | Publisher Full Text | Free Full Text

47. Liu TM, Woyach JA, Zhong Y, et al:: Hypermorphic mutation of phospholipase C, $\gamma 2$ acquired in ibrutinib-resistant CLL confers BTK independency upon B-cell receptor activation. Blood. 2015; 126(1): 61-8.

PubMed Abstract | Publisher Full Text | Free Full Text

48. Cheng S, Guo A, Lu P, et al.: Functional characterization of BTK ${ }^{\text {C481s }}$ mutation that confers ibrutinib resistance: exploration of alternative kinase inhibitors. Leukemia. 2015; 29(4): 895-900.

PubMed Abstract | Publisher Full Text

49. F Burger JA, Landau DA, Taylor-Weiner A, et al:: Clonal evolution in patients with chronic lymphocytic leukaemia developing resistance to BTK inhibition. Nat Commun. 2016; 7: 11589.

PubMed Abstract | Publisher Full Text | Free Full Text | F1000 Recommendation

50. Jain $\mathrm{P}$, Keating $\mathrm{M}$, Wierda $\mathrm{W}$, et al:: Outcomes of patients with chronic lymphocytic leukemia after discontinuing ibrutinib. Blood. 2015; 125(13): 2062-7.

PubMed Abstract | Publisher Full Text | Free Full Text

51. Maddocks KJ, Ruppert AS, Lozanski G, et al.: Etiology of Ibrutinib Therapy Discontinuation and Outcomes in Patients With Chronic Lymphocytic Leukemia. JAMA Oncol. 2015; 1(1): 80-7.

PubMed Abstract | Publisher Full Text | Free Full Text

52. F Jain P, Thompson PA, Keating M, et al.: Long-term outcomes for patients with chronic lymphocytic leukemia who discontinue ibrutinib. Cancer. 2017; 123(12): 2268-73.

PubMed Abstract | Publisher Full Text | F1000 Recommendation

53. Jones J, Choi MY, Mato AR, et al.: Venetoclax (VEN) Monotherapy for Patients with Chronic Lymphocytic Leukemia (CLL) Who Relapsed after or Were Refractory to Ibrutinib or Idelalisib. Blood. 2016; 128(22): 637. Reference Source

54. Mato AR, Hill BT, Lamanna N, et al.: Optimal Sequencing of Ibrutinib, Idelalisib, and Venetoclax in Chronic Lymphocytic Leukemia: Results from a Multi-Center Study of 683 Patients. Ann Oncol. 2017; 28(5): 1050-1056. PubMed Abstract | Publisher Full Text

55. Porcu P, Flinn I, Kahl BS, et al.: Clinical activity of duvelisib (IPI-145), a phosphoinositide-3-kinase- $\delta, \gamma$ inhibitor, in patients previously treated with ibrutinib. Blood. 2014; 124(21): 3335

Reference Source

56. Sharman JP, Shustov AR, Smith MR, et al.: Updated Results on the Clinical Activity of Entospletinib (GS-9973), a Selective Syk Inhibitor, in Patients with CLL Previously Treated with an Inhibitor of the B-Cell Receptor Signaling Pathway. Blood. 2016; 128(22): 3225.

Reference Source

57. El-Gamal D, Williams K, LaFollette TD, et al:: PKC- $\beta$ as a therapeutic target in CLL: PKC inhibitor AEB071 demonstrates preclinical activity in CLL. Blood. 2014; 124(9): 1481-91.

PubMed Abstract | Publisher Full Text | Free Full Text

58. Kopp N, Tschuri S, Haebe S, et al.: Newer-generation HSP90 inhibitors can overcome ibrutinib resistance and suppress proliferation in human mantle cell lymphoma in vitro and in vivo. Blood. 2014; 124(21): 1686.

Reference Source

59. F Hing ZA, Mantel R, Beckwith KA, et al.: Selinexor is effective in acquired resistance to ibrutinib and synergizes with ibrutinib in chronic lymphocytic leukemia. Blood. 2015; 125(20): 3128-32.

PubMed Abstract | Publisher Full Text | Free Full Text | F1000 Recommendation

60. Neuman LL, Ward R, Arnold D, et al.: First-in-Human Phase 1a Study of the Safety, Pharmacokinetics, and Pharmacodynamics of the Noncovalent Bruton Tyrosine Kinase (BTK) Inhibitor SNS-062 in Healthy Subjects. Blood. 2016; 128(22): 2032. Reference Source

61. Reiff S, Guinn D, Mantel R, et al:: Evaluation of the novel Bruton's tyrosinekinase (BTK) inhibitor GDC-0853 in chronic lymphocytic leukemia (CLL) with wildtype or C481S mutated BTK. J Clin Oncol. 2016; 3-7. Reference Source

62. Reiff SD, Mantel R, Smith LL, et al:: The Bruton's Tyrosine Kinase (BTK) Inhibitor ARQ 531 Effectively Inhibits Wild Type and C481S Mutant BTK and Is Superio to Ibrutinib in a Mouse Model of Chronic Lymphocytic Leukemia. Blood. 2016; 128(22): 3232 .

Reference Source

63. Woyach JA, Bojnik E, Ruppert AS, et al.: Bruton's tyrosine kinase (BTK) function is important to the development and expansion of chronic lymphocytic leukemia (CLL). Blood. 2014; 123(8): 1207-13. PubMed Abstract | Publisher Full Text | Free Full Text

64. Honigberg LA, Smith AM, Sirisawad M, et al:: The Bruton tyrosine kinase inhibitor PCl-32765 blocks B-cell activation and is efficacious in models of autoimmune disease and B-cell malignancy. Proc Natl Acad Sci U S A. 2010; 107(29): 13075-80.

PubMed Abstract | Publisher Full Text | Free Full Text

65. McMullen JR, Boey EJ, Ooi JY, et al.: Ibrutinib increases the risk of atria fibrillation, potentially through inhibition of cardiac PI3K-Akt signaling. Blood. 2014; 124(25): 3829-30.

PubMed Abstract | Publisher Full Text

66. Levade M, David E, Garcia C, et al.: Ibrutinib treatment affects collagen and von Willebrand factor-dependent platelet functions. Blood. 2014; 124(26): 3991-5. PubMed Abstract | Publisher Full Text

67. Kamel S, Horton L, Ysebaert L, et al.: Ibrutinib inhibits collagen-mediated but not ADP-mediated platelet aggregation. Leukemia. 2015; 29(4): 783-7. PubMed Abstract | Publisher Full Text

68. Alberelli MA, Innocenti I, Sica S, et al: PO-54 - Clinical and laboratory characterization of platelet dysfunction caused by ibrutinib treatment in patients with chronic lymphocytic leukemia. Thromb Res. 2016; 140 Suppl 1: S196. PubMed Abstract | Publisher Full Text

69. Patel V, Balakrishnan K, Bibikova E, et al: Comparison of Acalabrutinib, A Selective Bruton Tyrosine Kinase Inhibitor, with Ibrutinib in Chronic Lymphocytic Leukemia Cells. Clin Cancer Res. 2017; 23(14): 3734-43. PubMed Abstract | Publisher Full Text | Free Full Text

70. F Byrd JC, Harrington B, O'Brien S, et al:: Acalabrutinib (ACP-196) in Relapsed Chronic Lymphocytic Leukemia. N Engl J Med. 2016; 374(4): 323-32. PubMed Abstract | Publisher Full Text | Free Full Text | F1000 Recommendation

71. Walter HS, Jayne S, Rule SA, et al.: Long-term follow-up of patients with CLL treated with the selective Bruton's tyrosine kinase inhibitor ONO/GS-4059. Blood. 2017; 129(20): 2808-10.

PubMed Abstract | Publisher Full Text | Free Full Text

72. Tam C, Grigg AP, Opat S, et al.: The BTK Inhibitor, Bgb-3111, Is Safe, Tolerable, and Highly Active in Patients with Relapsed/ Refractory B-Cell Malignancies: Initial Report of a Phase 1 First-in-Human Trial. Blood. 2015; 126(23): 832 Reference Source

73. Tam CS, Opat S, Cull G, et al:: Twice Daily Dosing with the Highly Specific BTK Inhibitor, Bgb-3111, Achieves Complete and Continuous BTK Occupancy in Lymph Nodes, and Is Associated with Durable Responses in Patients (pts) with Chronic Lymphocytic Leukemia (CLL)/Small Lymphocytic Lymphoma (SLL). Blood. 2016; 128(22): 642. Reference Source

74. Bose P, Gandhi VV, Keating MJ: Pharmacokinetic and pharmacodynamic evaluation of ibrutinib for the treatment of chronic lymphocytic leukemia: rationale for lower doses. Expert Opin Drug Metab Toxicol. 2016; 1-12. PubMed Abstract | Publisher Full Text | Free Full Text

75. F Advani RH, Buggy JJ, Sharman JP, et al:: Bruton tyrosine kinase inhibitor ibrutinib (PCl-32765) has significant activity in patients with relapsed/ refractory B-cell malignancies. J Clin Oncol. 2013; 31(1): 88-94. PubMed Abstract | Publisher Full Text | Free Full Text | F1000 Recommendation

76. Chen SS, Chang BY, Chang S, et al:: BTK inhibition results in impaired CXCR4 chemokine receptor surface expression, signaling and function in chronic lymphocytic leukemia. Leukemia. 2016; 30(4): 833-43. PubMed Abstract | Publisher Full Text | Free Full Text

77. Cervantes-Gomez F, Kumar Patel V, Bose P, et al.: Decrease in total protein level of Bruton's tyrosine kinase during ibrutinib therapy in chronic lymphocytic leukemia lymphocytes. Leukemia. 2016; 30(8): 1803-4. PubMed Abstract | Publisher Full Text

78. $\mathrm{F}$ Mato $\mathrm{AR}$, Timlin $\mathrm{C}$, Ujjani $\mathrm{C}$, et al:: Comparable outcomes in chronic lymphocytic leukaemia (CLL) patients treated with reduced-dose ibrutinib: results from a multi-centre study. Br J Haematol. 2017. PubMed Abstract | Publisher Full Text | F1000 Recommendation

79. $F$ Barr PM, Brown JR, Hillmen P, et al.: Impact of ibrutinib dose adherence on therapeutic efficacy in patients with previously treated CLL/SLL. Blood. 2017; 129(19): 2612-5.

PubMed Abstract | Publisher Full Text | Free Full Text | F1000 Recommendation

80. Burger JA, Keating MJ, Wierda WG, et al.: Safety and activity of ibrutinib plus rituximab for patients with high-risk chronic lymphocytic leukaemia: a singlearm, phase 2 study. Lancet Oncol. 2014; 15(10): 1090-9. PubMed Abstract | Publisher Full Text | Free Full Text

81. Jaglowski SM, Jones JA, Nagar V, et al.: Safety and activity of BTK inhibitor ibrutinib combined with ofatumumab in chronic lymphocytic leukemia: a phase 1b/2 study. Blood. 2015; 126(7): 842-50. PubMed Abstract | Publisher Full Text | Free Full Text

82. Kohrt HE, Sagiv-Barfi I, Rafiq S, et al:: Ibrutinib antagonizes rituximabdependent NK cell-mediated cytotoxicity. Blood. 2014; 123(12): 1957-60. PubMed Abstract | Publisher Full Text | Free Full Text

83. F Chanan-Khan A, Cramer P, Demirkan F, et al.: Ibrutinib combined with bendamustine and rituximab compared with placebo, bendamustine, an rituximab for previously treated chronic lymphocytic leukaemia or small lymphocytic lymphoma (HELIOS): a randomised, double-blind, phase 3 study. Lancet Oncol. 2016; 17(2): 200-11.

PubMed Abstract | Publisher Full Text | F1000 Recommendation

84. Furman RR, Sharman JP, Coutre SE, et al.: Idelalisib and rituximab in relapsed 
chronic lymphocytic leukemia. N Engl J Med. 2014; 370(11): 997-1007. PubMed Abstract | Publisher Full Text | Free Full Text

85. Yang Q, Chen LS, Ha MJ, et al:: Idelalisib Impacts Cell Growth through Inhibiting Translation-Regulatory Mechanisms in Mantle Cell Lymphoma. Clin Cancer Res. 2017; 23(1): 181-92.

PubMed Abstract | Publisher Full Text | Free Full Text

86. Modi $\mathrm{P}$, Balakrishnan $\mathrm{K}$, Yang $\mathrm{Q}$, et al.: Idelalisib and bendamustine combination is synergistic and increases DNA damage response in chronic lymphocytic leukemia cells. Oncotarget. 2017; 8(10): 16259-74. PubMed Abstract | Publisher Full Text | Free Full Text

87. F Zelenetz AD, Barrientos JC, Brown JR, et al:: Idelalisib or placebo in combination with bendamustine and rituximab in patients with relapsed or refractory chronic lymphocytic leukaemia: interim results from a phase 3 , randomised, double-blind, placebo-controlled trial. Lancet Oncol. 2017; 18(3): 297-311.

PubMed Abstract | Publisher Full Text | Free Full Text | F1000 Recommendation

88. F Jones JA, Robak T, Brown JR, et al.: Efficacy and safety of idelalisib in combination with ofatumumab for previously treated chronic lymphocytic leukaemia: an open-label, randomised phase 3 trial. Lancet Haematol. 2017; 4(3): e114-e126

PubMed Abstract | Publisher Full Text | F1000 Recommendation

89. F Lampson BL, Kasar SN, Matos TR, et al:: Idelalisib given front-line for treatment of chronic lymphocytic leukemia causes frequent immune-mediated hepatotoxicity. Blood. 2016; 128(2): 195-203.

PubMed Abstract | Publisher Full Text | Free Full Text | F1000 Recommendation

90. F Compagno $\mathrm{M}$, Wang $\mathrm{Q}$, Pighi $\mathrm{C}$, et al:: Phosphatidylinositol 3-kinase $\boldsymbol{\delta}$ blockade increases genomic instability in B cells. Nature. 2017; 542(7642): 489-93.

PubMed Abstract | Publisher Full Text | Free Full Text | F1000 Recommendation

91. Vangapandu HV, Jain N, Gandhi V: Duvelisib: a phosphoinositide-3 kinase $\delta / \gamma$ inhibitor for chronic lymphocytic leukemia. Expert Opin Investig Drugs. 2017; 26(5): 625-32.

PubMed Abstract | Publisher Full Text | Free Full Text

92. Balakrishnan K, Peluso M, Fu M, et al.: The phosphoinositide-3-kinase (PI3K)delta and gamma inhibitor, IPI-145 (Duvelisib), overcomes signals from the PI3K/AKT/S6 pathway and promotes apoptosis in CLL. Leukemia. 2015; 29(9): 1811-22.

PubMed Abstract | Publisher Full Text | Free Full Text

93. Dong S, Guinn D, Dubovsky JA, et al:: IPI-145 antagonizes intrinsic and extrinsic survival signals in chronic lymphocytic leukemia cells. Blood. 2014; 124(24): 3583-6.

PubMed Abstract | Publisher Full Text | Free Full Text

94. O'Brien S, Patel M, Kahl BS, et al:: Duvelisib (IPI-145), a PI3K- $\delta, \gamma$ inhibitor, is clinically active in patients with relapsed/refractory chronic lymphocytic leukemia. Blood. 2014; 124(21): 3334.

Reference Source

95. Patel MR, O'Brien SM, Faia K, et al.: Early clinical activity and pharmacodynamic effects of duvelisib, a PI3K- $\delta, \gamma$ inhibitor, in patients with treatment-naïve CLL. J Clin Oncol. 2015; 33: 7074.

Reference Source

96. Flinn IW, Cherry M, Maris M, et al.: Combination trial of duvelisib (IPI-145) with bendamustine, rituximab, or bendamustine/rituximab in patients with lymphoma or chronic lymphocytic leukemia. Blood. 2015; 126(23): 3928. Reference Source

97. Davids MS, Kim HT, Gilbert E, et al.: Preliminary results of a phase lb study of duvelisib in combination with FCR (dFCR) in previously untreated, younge patients with CLL. Blood. 2015; 126(23): 4158 .

Reference Source

98. F Kwok M, Rawstron AC, Varghese A, et al:: Minimal residual disease is an independent predictor for 10-year survival in CLL. Blood. 2016; 128(24): $2770-3$

PubMed Abstract | Publisher Full Text | F1000 Recommendation

99. F Del Gaizo Moore V, Brown JR, Certo M, et al.: Chronic lymphocytic leukemia requires $B C L 2$ to sequester prodeath $B I M$, explaining sensitivity to $B C L 2$ antagonist ABT-737. J Clin Invest. 2007; 117(1): 112-21.

PubMed Abstract | Publisher Full Text | Free Full Text | F1000 Recommendation

100. Roberts AW, Seymour JF, Brown JR, et al: Substantial susceptibility of chronic lymphocytic leukemia to BCL2 inhibition: results of a phase I study of navitoclax in patients with relapsed or refractory disease. J Clin Oncol. 2012; 30(5): 488-96.

PubMed Abstract | Publisher Full Text | Free Full Text

101. F Mason KD, Carpinelli MR, Fletcher Jl, et al.: Programmed anuclear cell death delimits platelet life span. Cell. 2007; 128(6): 1173-86. PubMed Abstract | Publisher Full Text | F1000 Recommendation

102. F Souers AJ, Leverson JD, Boghaert ER, et al.: ABT-199, a potent and selective BCL-2 inhibitor, achieves antitumor activity while sparing platelets. Nat Med. 2013; 19(2): 202-8

PubMed Abstract | Publisher Full Text | F1000 Recommendation

103. F Roberts AW, Davids MS, Pagel JM, et al:: Targeting BCL2 with Venetoclax in Relapsed Chronic Lymphocytic Leukemia. N Engl J Med. 2016; 374(4): 311-22. PubMed Abstract | Publisher Full Text | F1000 Recommendation
104. F Stilgenbauer S, Eichhorst B, Schetelig J, et al.: Venetoclax in relapsed or fractory chronic lymphocytic leukaemia with $17 \mathrm{p}$ deletion: a multicentre open-label, phase 2 study. Lancet Oncol. 2016; 17(6): 768-78. PubMed Abstract | Publisher Full Text | F1000 Recommendation

105. F Seymour JF, Ma S, Brander DM, et al.: Venetoclax plus rituximab in relapsed or refractory chronic lymphocytic leukaemia: a phase $1 \mathrm{~b}$ study. Lancet Oncol. 2017; 18(2): 230-40.

PubMed Abstract | Publisher Full Text | Free Full Text | F1000 Recommendation

106. Thompson PA, Tam CS, O'Brien SM, et al.: Fludarabine, cyclophosphamide, and rituximab treatment achieves long-term disease-free survival in IGHV-mutated chronic lymphocytic leukemia. Blood. 2016; 127(3): 303-9.

PubMed Abstract | Publisher Full Text | Free Full Text

107. Davids MS, Kim HT, Brander DM, et al:: Initial Results of a Multicenter, Phase II Study of Ibrutinib Plus FCR (iFCR) As Frontline Therapy for Younger CLL Patients. Blood. 2016; 128(22): 3243.

Reference Source

108. Benjamini $\mathrm{O}$, Jain $\mathrm{P}$, Trinh $\mathrm{L}$, et al: Second cancers in patients with chronic lymphocytic leukemia who received frontline fludarabine, cyclophosphamide and rituximab therapy: distribution and clinical outcomes. Leuk Lymphoma. 2015; 56(6): 1643-50

PubMed Abstract | Publisher Full Text | Free Full Text

109. Jain N, Thompson PA, Burger JA, et al.: Ibrutinib, fludarabine, cyclophosphamide, and obinutuzumab (GA101) (iFCG) for previously untreated patients with chronic lymphocytic leukemia (CLL) with mutated IGHV and non-del (17p). J Clin Oncol. 2017; 35: 7522. Reference Source

110. Thompson PA, Wierda WG: Eliminating minimal residual disease as a therapeutic end point: working toward cure for patients with CLL. Blood. 2016; 127(3): 279-86.

PubMed Abstract | Publisher Full Text | Free Full Text

111. Cervantes-Gomez F, Lamothe B, Woyach JA, et al.: Pharmacological and Protein Profiling Suggests Venetoclax (ABT-199) as Optimal Partner with Ibrutinib in Chronic Lymphocytic Leukemia. Clin Cancer Res. 2015; 21(16): 3705-15. PubMed Abstract | Publisher Full Text | Free Full Text

112. Deng J, Isik E, Fernandes SM, et al.: Bruton's tyrosine kinase inhibition increases BCL-2 dependence and enhances sensitivity to venetoclax in chronic lymphocytic leukemia. Leukemia. 2017; 31(10): 2075-2084. PubMled Abstract | Publisher Full Text | Free Full Text

113. F Byrd JC, Furman RR, Coutre SE, et al:: Targeting BTK with ibrutinib in relapsed chronic lymphocytic leukemia. N Engl J Med. 2013; 369(1): 32-42. PubMed Abstract | Publisher Full Text | Free Full Text | F1000 Recommendation

114. Jones JA, Woyach J, Awan FT, et al:: Phase 1b Results of a Phase 1b/2 Study of Obinutuzmab, Ibrutinib, and Venetoclax in Relapsed/Refractory Chronic Lymphocytic Leukemia (CLL). Blood. 2016; 128(22): 639 Reference Source

115. Chen Q, Jain N, Ayer T, et al.: Economic Burden of Chronic Lymphocytic Leukemia in the Era of Oral Targeted Therapies in the United States. J Clin Oncol. 2017; 35(2): 166-74.

PubMed Abstract | Publisher Full Text | Free Full Text

116. Patel VM, Balakrishnan $\mathrm{K}$, Douglas $\mathrm{M}$, et al.: Duvelisib treatment is associated with altered expression of apoptotic regulators that helps in sensitization of chronic lymphocytic leukemia cells to venetoclax (ABT-199). Leukemia. 2017 31(9): 1872-81.

PubMed Abstract | Publisher Full Text | Free Full Text

117. Ding W, LaPlant BR, Call TG, et al.: Pembrolizumab in patients with CLL and Richter transformation or with relapsed CLL. Blood. 2017; 129(26): 3419-3427. PubMed Abstract | Publisher Full Text | Free Full Text

118. F Sagiv-Barfi I, Kohrt HEK, Czerwinski DK, et al:: Therapeutic antitumor immunity by checkpoint blockade is enhanced by ibrutinib, an inhibitor of both BTK and ITK. Proc Natl Acad Sci U S A. 2015; 112(9): E966-72. PubMed Abstract | Publisher Full Text | Free Full Text | F1000 Recommendation

119. Dubovsky JA, Beckwith KA, Natarajan G, et al.: Ibrutinib is an irreversible molecular inhibitor of ITK driving a Th1-selective pressure in T lymphocytes. Blood. 2013; 122(15): 2539-49.

PubMed Abstract | Publisher Full Text | Free Full Text

120. Bose $\mathrm{P}$, Gandhi V, Konopleva M: Pathways and mechanisms of venetoclax resistance. Leuk Lymphoma. 2017; 58(9): 1-17. PubMed Abstract | Publisher Full Text | Free Full Text

121. F Leverson JD, Zhang $\mathrm{H}$, Chen J, et al.: Potent and selective small-molecule MCL-1 inhibitors demonstrate on-target cancer cell killing activity as single agents and in combination with ABT-263 (navitoclax). Cell Death Dis. 2015; 6 : e1590.

PubMed Abstract | Publisher Full Text | Free Full Text | F1000 Recommendation

122. $\mathrm{F}$ Lee $\mathrm{T}$, Bian $\mathrm{Z}$, Zhao B, et al.: Discovery and biological characterization of potent myeloid cell leukemia-1 inhibitors. FEBS Lett. 2017; 591(1): 240-51. PubMed Abstract | Publisher Full Text | Free Full Text | F1000 Recommendation

123. $F$ Kotschy A, Szlavik Z, Murray J, et al:: The MCL1 inhibitor $\mathbf{S 6 3 8 4 5}$ is tolerable and effective in diverse cancer models. Nature. 2016; 538(7626): 477-82. PubMled Abstract | Publisher Full Text | F1000 Recommendation

124. Lincoln SE, Yang S, Cline MS, et al:: Consistency of BRCA1 and BRCA2 Variant 
Classifications Among Clinical Diagnostic Laboratories. JCO Precis Oncol. $2017 ; 1$

PubMed Abstract | Publisher Full Text | Free Full Text

125. Bose $\mathrm{P}$, Simmons GL, Grant S: Cyclin-dependent kinase inhibitor therapy for hematologic malignancies. Expert Opin Investig Drugs. 2013; 22(6):

723-38.

PubMed Abstract | Publisher Full Text | Free Full Text

126. Byrd JC, Lin TS, Dalton JT, et al.: Flavopiridol administered using a pharmacologically derived schedule is associated with marked clinical efficacy in refractory, genetically high-risk chronic lymphocytic leukemia. Blood. 2007; 109(2): 399-404.

PubMed Abstract | Publisher Full Text | Free Full Text

127. Flynn $\mathrm{J}$, Jones $\mathrm{J}$, Johnson AJ, et al.: Dinaciclib is a novel cyclin-dependent kinase inhibitor with significant clinical activity in relapsed and refractory chronic lymphocytic leukemia. Leukemia. 2015; 29(7): 1524-9.

PubMed Abstract | Publisher Full Text | Free Full Text
128. Galletti G, Scielzo C, Barbaglio F, et al:: Targeting Macrophages Sensitizes Chronic Lymphocytic Leukemia to Apoptosis and Inhibits Disease Progression. Cell Rep. 2016; 14(7): 1748-60.

PubMed Abstract | Publisher Full Text

129. van Attekum MHA, Terpstra S, Slinger E, et al.: Macrophages confer survival signals via CCR1-dependent translational MCL-1 induction in chronic lymphocytic leukemia. Oncogene. 2017; 36(26): 3651-60. PubMed Abstract | Publisher Full Text | Free Full Text

130. Tap WD, Wainberg ZA, Anthony SP, et al:: Structure-Guided Blockade of CSF1R Kinase in Tenosynovial Giant-Cell Tumor. N Engl J Med. 2015; 373(5): 428-37. PubMed Abstract | Publisher Full Text

131. Strachan DC, Ruffell $B$, Oei $Y$, et al:: CSF1R inhibition delays cervical and mammary tumor growth in murine models by attenuating the turnover of tumor-associated macrophages and enhancing infiltration by $C D 8^{+} \mathrm{T}$ cells. Oncoimmunology. 2013; 2(12): e26968.

PubMed Abstract | Publisher Full Text | Free Full Text 


\section{Open Peer Review}

\section{Current Peer Review Status:}

\section{Editorial Note on the Review Process}

Faculty Reviews are review articles written by the prestigious Members of Faculty Opinions. The articles are commissioned and peer reviewed before publication to ensure that the final, published version is comprehensive and accessible. The reviewers who approved the final version are listed with their names and affiliations.

\section{The reviewers who approved this article are:}

\section{Version 1}

\section{Emili Montserrat}

Department of Hematology Hospital Clinic, University of Barcelona, Barcelona, Spain

Competing Interests: No competing interests were disclosed.

\section{Jacqueline Barrientos}

CLL Research and Treatment Program, Department of Internal Medicine, Hofstra Northwell School of Medicine, Hempstead, New York, USA

Competing Interests: No competing interests were disclosed.

The benefits of publishing with F1000Research:

- Your article is published within days, with no editorial bias

- You can publish traditional articles, null/negative results, case reports, data notes and more

- The peer review process is transparent and collaborative

- Your article is indexed in PubMed after passing peer review

- Dedicated customer support at every stage

For pre-submission enquiries, contact research@f1000.com 